\title{
PENGARUH PENAMBAHANPOLLARD DAN BEKATUL DALAM PEMBUATAN SILASE RUMPUT ODOT (Pennisetum purpureum, Cv. Mott) TERHADAP KECERNAAN DAN PRODUKSI GAS SECARA IN VITRO
}

\author{
Alifia Imtinatul Fajri ${ }^{1)}$, Hartutik ${ }^{2)}$ dan Artharini Irsyammawati ${ }^{2)}$ \\ ${ }^{1)}$ Mahasiswa Pascasarjana Fakultas Peternakan Universitas Brawijaya, Malang 65145, Indonesia \\ ${ }^{2)}$ Dosen Minat Nutrisi dan Makanan Ternak, Fakultas Peternakan Universitas Brawijaya, Malang 65145, \\ Indonesia \\ Email:alifiafajri13@gmail.com
}

\begin{abstract}
ABSTRAK
Tujuan dari penelitian ini adalah untuk mengevaluasi pengaruh penambahan pollard dan bekatul dalam pembuatan silase rumput odot (Pennisetum purpureum,cv. Mott) terhadap kecernaan dan produksi gas secara in vitro. Materi penelitian adalah rumput odot, pollard dan bekatul sebagai bahan aditif. Metode penelitian yang digunakan adalah Rancangan Acak Kelompok (RAK) yang terdiri dari 4 perlakuan dan 3 kali pengelompokkan berdasarkan pengambilan cairan rumen. Perlakuan terdiri dari: $P_{0}=$ rumput odot tanpa bahan aditif, $P_{1}=$ rumput odot + pollard $20 \%, P_{2}=$ rumput odot + bekatul $20 \%, P_{3}=$ rumput odot + pollard 10\% + bekatul 10\%. Data yang diperoleh dianalisis dengan analisis varian dan dilanjutkan dengan uji Duncan's Multiple Range Test (DMRT). Variabel yang diamati yaitu kecernaan bahan kering (KcBK) dan kecernaan bahan organik (KcBO), produksi gas (PG) kumulatif, serta degradasi dari residu PG. Hasil penelitian menunjukkan bahwa perlakuan memberikan pengaruh yang tidak nyata $(P>0,05)$ terhadap $K c B K$ dan $K c B O$, namun memberikan pengaruh yang sangat nyata $(P<0,01)$ pada $P G$ kumulatif dan degradasi. Dapat disimpulkan bahwa rumput odot $+20 \%$ pollard $\left(P_{l}\right)$ merupakan perlakuan terbaik ditinjau dari nilai KcBK (62,34\%), KcBO (68,18\%) serta didukung dengan nilai $P G$ kumulatif dan degradasi yang tinggi. Disarankan untuk melakukan penelitian lebih lanjut mengenai komponen serat dan uji in vivo.
\end{abstract}

Kata kunci: Bekatul, kecernaan, pollard, produksi gas, silase rumput odot

How to Cite :

Fajri, A. I., Hartutik., \& Irsyammawati, A. (2018). Pengaruh Penambahanpollard dan Bekatul dalam Pembuatan Silase Rumput Odot (Pennisetum purpureum, Cv. Mott) Terhadap Kecernaan dan Produksi Gas Secara In Vitro. Jurnal Nutrisi Ternak Tropis, 1 (1) 9-17
*Corresponding author:

Alifia Imtinatul Fajri

Email : alifiafajri13@gmail.com

Faculty of Animal Science, Brawijaya University, Veteran Street, Malang, East Java, Indonesia. 65145 


\section{ABSTRACT}

The purpose of this research was to evaluate pollard and rice bran in dwarf elephant grass silage (Pennisetum purpureum, cv. Mott) processing on in vitro digestibility and gas production. The materials were dwarf elephant grass, pollard and rice bran as additives. The research was arranged in randomized block design with 4 treatments and 3 replication based on rumen liquid collection. The treatments were: dwarf elephant grass without additive $\left(T_{0}\right)$, $d$ warf elephant grass $+20 \%$ pollard $\left(T_{1}\right)$, dwarf elephant grass $+20 \%$ rice bran $\left(T_{2}\right)$, dwarf elephant grass $+10 \%$ pollard $+10 \%$ rice bran $\left(T_{3}\right)$. Collected data were analyzed by analysis of variance and continued with Duncan's Multiple Range Test (DMRT). Variables measured were in vitro dry matter digestibility (DMD) and organic matter digestibility $(O M D)$, cumulative gas production (GP) and degradability from GP residue. The result showed that the treatments didn't significantly effect $(P>0.05)$ on DMD and OMD but highly significant effect $(P<0.01)$ on cumulative GP and degradability. It could be concluded that $d$ warf elephant grass $+20 \%$ pollard $\left(T_{1}\right)$ was the best treatment based on DMD $(62.34 \%)$, OMD (68.18\%) and supported by highly number of cumulative GP and degradability. Thus it was suggested to do further research on fiber composition and in vivo assay.

Keywords: Digestibility, dwarf elephant grass silage, gas production, pollard, rice bran

\section{PENDAHULUAN}

Hijauan dalam pakan ternak ruminansia merupakan salah satu hal yang dapat mempengaruhi produktivitas ternak, namun ketersediaannya sangat bergantung terhadap musim. Produksi hijauan pada musim penghujan akan melimpah baik secara kuantitas maupun kualitas serta akan mengalami penurunan produksi pada musim kemarau. Hal ini dipengaruhi oleh jumlah air pada tanah, sehingga akan berdampak pada penyerapan unsur hara (Musyarofah dkk., 2007). Diperlukan upaya untuk menyediakan hijauan pakan yang berkualitas baik dan berkelanjutan pemberiannya dengan teknologi awetan segar atau silase.

Rumput odot (Pennisetum purpureum, cv. Mott) merupakan rumput merumpun tropis tahunan yang memiliki produktivitas cukup tinggi yakni mencapai 52-57 ton/ha produksi segar (Yasin et al., 2003). Rumput ini memiliki kandungan Water Soluble Carbohydrate (WSC) yang rendah yakni 4,1\% (Santos et al., 2013). Oleh karena itu penambahan bahan aditif perlu dilakukan untuk meningkatkan kualitas silase.

Pollard merupakan bahan pakan yang berasal dari pengayakan saat proses penggilingan gandum menjadi tepung terigu (FAO, 2016). Pada proses produksi tepung terigu, dihasilkan tepung terigu sebanyak $74 \%$ serta limbahnya berupa bran $10 \%$, pollard $13 \%$ dan bahan untuk lem kayu lapis 3\% (Arief dan Arianti, 2000). Bekatul merupakan bahan pakan yang berasal dari hasil samping proses penggilingan padi untuk menjadi beras. Setiap bulir padi terdiri dari beras $63-72 \%$, bekatul $8-12 \%$, sekam 15-20\% dan menir 5\% (Wirawati dan Nirmagustina, 2009). Pollard dan bekatul memiliki WSC masing-masing sebesar $12,52 \%$ dan $5,42 \%$ (Despal dkk., 2011 dan Jayathilake et al., 2012).Berdasarkan uraian tersebut, perlu dilakukan penelitian lebih lanjut yang bertujuan untuk mengetahui pengaruh penambahan pollard dan bekatul dalam pembuatan silase rumput odot terhadap kecernaan dan produksi gas secara in vitro.

\section{MATERI DAN METODE}

Penelitian dilaksanakan pada 16 Januari sampai 17 Maret 2017. Pembuatan silase sertapengukuran kecernaan dan produksi gas secara in vitro dilaksanakan di Laboratorium Nutrisi dan Makanan Ternak, 
Fakultas Peternakan, Universitas Brawijaya Malang.

Materi yang digunakan dalam penelitian ini adalah silase rumput odot dengan umur potong 60 hari yang ditambahkan bahan aditif berupapollarddan bekatul dengan Protein Kasar (PK) masingmasing $16,47 \%$ dan $9,69 \%$ dari Bahan Kering (BK); cairan rumen dari sapi betina berfistula yang berumur 8 tahun dengan bobot $\pm 500 \mathrm{~kg}$ diambil pada pagi hari sebelum pemberian pakan untuk pengukuran produksi gas dan 4 jam setelah pemberian pakan untuk pengukuran kecernaan; seperangkat bahan kimia untuk pengukuran kecernaan dan produksi gas in vitro.

Pengukuran kecernaan dua tahapin vitro (fermentatif dan hidrolitis) dengan waktu inkubasi masing-masing 48 jam dilakukan menggunakan tabung fermentordengan suhu $39^{\circ} \mathrm{C}$.Analisis produksi gas dilakukan dengan inkubasi selama 96 jam pada suhu $39^{\circ} \mathrm{C}$ secaraanaerobmenggunakan syringe berskala.
Metode yang digunakan adalah metode percobaan di laboratorium dengan Rancangan Acak Kelompok (RAK) menggunakan 4 perlakuan dan 3 kelompok berdasarkan pengambilan cairan rumen sebagai berikut:

$$
\begin{aligned}
& \mathrm{P}_{0}=\text { Rumput odot } \\
& \mathrm{P}_{1}=\mathrm{P}_{0}+\text { pollard 20\% } \mathrm{BK} \mathrm{P}_{0} \\
& \mathrm{P}_{2}=\mathrm{P}_{0}+\text { bekatul } 20 \% \mathrm{BK} \mathrm{P}_{0} \\
& \mathrm{P}_{3}=\mathrm{P}_{0}+\text { pollard } \quad 10 \% \quad \mathrm{BK} \quad \mathrm{P}_{0}+ \\
& \text { bekatul10\%dari BK } \mathrm{P}_{0}
\end{aligned}
$$

\section{Variabel penelitian:}

Variabel yang diamati meliputi kecernaan $\mathrm{BK}(\mathrm{KcBK})$ dan $\mathrm{BO}(\mathrm{KcBO})$ in vitro menurut Tilley and Terry (1963), produksi gas kumulatif menurut Menkee and Steingas (1979), potensi produksi gas (b), laju produksi gas (c) yang ditentukan dengan persamaan eksponensial Ørskov and McDonald (1979), serta degradasi residu produksi gas 96 jam. Analisis data menggunakan analisis ragam dengan Uji Jarak Berganda Duncan untuk mengetahui perbedaan masing-masing perlakuan.

\section{HASIL DAN PEMBAHASAN}

Kandungan nutrien:

Tabel 1. Kandungan nutrien bahan baku pembuatan silase

\begin{tabular}{lcccccc}
\hline \multirow{2}{*}{ Bahan } & \multirow{2}{*}{ BK $(\%)$} & \multicolumn{5}{c}{ Kandungan nutrien $(\% \mathrm{BK})^{*}$} \\
\cline { 3 - 7 } & & $\mathrm{BO}(\%)$ & PK $(\%)$ & SK $(\%)$ & LK $(\%)$ & Abu (\%) \\
\hline Rumput odot & 9,57 & 81,91 & 13,16 & 30,64 & 2,35 & 18,09 \\
Pollard & 88,17 & 95,22 & 16,47 & 8,04 & 4,7 & 4,78 \\
Bekatul & 90,86 & 89,27 & 9,69 & 16,93 & 7,7 & 10,73 \\
\hline
\end{tabular}

Keterangan:

1)Berdasarkan $100 \% \mathrm{BK}$

2) Hasil analisis Laboratorium Nutrisi dan Makanan Ternak Fakultas

PeternakanUniversitas Brawijaya (2017) 3)Putra (2017)

Tabel 1 menunjukkan bahwa bahan aditif pollard yang digunakan telah sesuai dengan persyaratan mutu SNI 2014 yakni PK min $15 \%$, SK min $8 \%$, LK min 3,5\% dan abu maks 5\% (Badan Standardisasi Nasional, 2014). Materi bekatul yang digunakan sebagai bahan aditif juga sesuai dengan NRC (2016) yang menyebutkan bahwa bekatul memiliki kandungan BK min $89 \%$, PK min $8,9 \%$ serta LK min $1,9 \%$. 
Tabel 2. Kandungan nutrien perlakuan setelah ensilase

\begin{tabular}{ccccccc}
\hline \multirow{2}{*}{ Perlakuan } & \multirow{2}{*}{$\mathrm{BK}(\%)$} & \multicolumn{5}{c}{ Kandungan nutrien $(\% \mathrm{BK})^{*}$} \\
\cline { 3 - 7 } & & $\mathrm{BO}(\%)$ & $\mathrm{PK}(\%)$ & $\mathrm{SK}(\%)$ & LK $(\%)$ & Abu $(\%)$ \\
\hline $\mathrm{P}_{0}$ & 13,88 & 80,76 & 9,89 & 34,77 & 3,03 & 18,65 \\
$\mathrm{P}_{1}$ & 13,28 & 85,10 & 12,60 & 31,70 & 3,58 & 14,90 \\
$\mathrm{P}_{2}$ & 13,67 & 83,64 & 11,35 & 30,32 & 3,99 & 16,36 \\
$\mathrm{P}_{3}$ & 13,68 & 83,74 & 12,44 & 29,74 & 5,84 & 16,26 \\
\hline
\end{tabular}

Keterangan:

1)* Berdasarkan $100 \% \mathrm{BK}$

2) Hasil analisis Laboratorium Nutrisi dan Makanan Ternak Fakultas Peternakan Universitas Brawijaya (2017)

3) Putra (2017)

Kandungan nutrien masing-masing perlakuan mengalami peningkatan (Tabel 2). Hal ini dikarenakan adanya penambahan bahan aditif yang berbeda pada silase rumput odot. $\mathrm{PK}$ pakan kontrol $\left(\mathrm{P}_{0}\right)$ lebih rendah dari perlakuan lain, hal ini disebabkan tidak adanya penambahan bahan aditif baik pollard, bekatul maupun campuran keduanyasehingga tidak ada tambahan nilai PK dalam $\mathrm{P}_{0} . \mathrm{P}_{1}$ menghasilkan SK tertinggi diantara perlakuan dengan penambahan bahan aditif, hal ini disebabkan karena komponen serat. Mutmainah dkk. (2010) menjelaskan tinggi rendahnya penurunan SK erat kaitannya dengan komponen penyusun SK terutama lignin.

Kecernaan in vitro:

Tabel 3.Rataan KcBK dan KcBO perlakuan setelah ensilase

\begin{tabular}{cll}
\hline Perlakuan & $\mathrm{KcBK}(\%)$ & $\mathrm{KcBO}(\%)$ \\
\hline $\mathrm{P}_{0}$ & $55,31 \pm 7,95$ & $60,09 \pm 9,05$ \\
$\mathrm{P}_{1}$ & $62,34 \pm 11,47$ & $68,18 \pm 12,60$ \\
$\mathrm{P}_{2}$ & $57,79 \pm 11,67$ & $65,54 \pm 12,86$ \\
$\mathrm{P}_{3}$ & $57,73 \pm 7,84$ & $64,20 \pm 8,41$ \\
\hline
\end{tabular}

Keterangan: KcBK dan $\mathrm{KcBO}$ menunjukkan pengaruh yang tidak nyata $(\mathrm{P}>0,05)$ antar perlakuan

Hasil analisis ragam menunjukkan bahwa perlakuan silase rumput odot dengan penambahan bahan aditif berbeda memberikan pengaruh yang tidak nyata $(\mathrm{P}>0,05)$ terhadap $\mathrm{KcBK}$ maupun $\mathrm{KcBO}$ secara in vitro (Tabel 3). Nilai kecernaan $\mathrm{P}_{0}$ cenderung lebih rendah dibandingkan perlakuan lain disebabkan karena tidak adanya penambahan bahan aditif dalam pakan sehingga menyebabkan rendahnya WSC. Rendahnya WSC pada perlakuan akan menyebabkan rendahnya aktivitas Bakteri Asam Laktat (BAL) dalam mendegradasi pakan menjadi asam organik terutama asam laktat (Ni et al., 2015). Selain itu, rendahnya nilai kecernaan perlakuan kontrol disebabkan karena tingginya kandungan SK perlakuan (Tabel 2). Tillman dkk. (1983) menyatakan bahwa
SK memiliki pengaruh yang besar terhadap kecernaan pakan. Kandungan SK yang lebih rendah menyebabkan KcBK lebih tinggi, begitu juga sebaliknya. $\mathrm{P}_{1}$ memiliki kecenderungan nilai kecernaan yang tinggi. Hal ini disebabkan karena tingginya kandungan BO pada bahan baku (Tabel 1) sehingga menyebabkan tingginya kandungan BO perlakuan. Hal ini sesuai dengan Tillman dkk. (1983) yang menyatakan bahwa kecernaan memiliki pengaruh yang erat dengan kandungan nutrien.

\section{Produksi gas in vitro:}

Hasil analisis ragam menunjukkan bahwa perlakuan silase rumput odot dengan penambahan bahan aditif berbeda memberikan pengaruh yang sangat nyata $(\mathrm{P}<0,01)$ terhadap produksi gas kumulatif 
secara in vitro (Tabel 4). $\mathrm{P}_{3}$ menghasilkan produksi gas kumulatif terbaik diantara perlakuan dengan penambahan bahan aditif, hal ini disebabkan karena tingginya kandungan BO perlakuan (Tabel 2). Kandungan BO difermentasi oleh mikroba rumen menghasilkan VFA sehingga berdampak pada tingginya produksi gas.
Ramdani dkk. (2017) menyebutkan bahwa produksi gas memiliki keterkaitan dengan nilai degradasi $\mathrm{BO}$ pakan oleh mikroba dalam cairan rumen. Semakin tinggi populasi mikroba dalam cairan rumen, maka semakin tinggi pula BO pakan yang mampu didegradasi dan gas yang dihasilkan akan semakin meningkat.

Tabel 4.Rataan nilai produksi gas kumulatif dan parameter produksi gas perlakuan setelahensilase

\begin{tabular}{cccc}
\hline Perlakuan & $\begin{array}{c}\text { Produksi gas inkubasi } \\
96 \text { jam }(\mathrm{ml} / 200 \mathrm{mg} \mathrm{BK})\end{array}$ & $\begin{array}{c}\text { Nilai b } \\
(\mathrm{ml} / 200 \mathrm{mg} \mathrm{BK})\end{array}$ & $\begin{array}{c}\text { Nilai c } \\
(\mathrm{ml} / \mathrm{jam})\end{array}$ \\
\hline $\mathrm{P}_{0}$ & $31,49 \pm 2,16^{\mathrm{a}}$ & $66,42 \pm 12,89$ & $0,0079 \pm 0,0028$ \\
$\mathrm{P}_{1}$ & $35,86 \pm 2,23^{\mathrm{b}}$ & $59,56 \pm 7,41$ & $0,0111 \pm 0,0022$ \\
$\mathrm{P}_{2}$ & $34,60 \pm 1,87^{\mathrm{ab}}$ & $76,11 \pm 40,45$ & $0,0093 \pm 0,0045$ \\
$\mathrm{P}_{3}$ & $38,15 \pm 4,10^{\mathrm{b}}$ & $75,31 \pm 26,70$ & $0,0095 \pm 0,0042$ \\
\hline
\end{tabular}

Keterangan: ${ }^{a-b}$ Superskrip yang berbeda pada kolom yang sama menunjukkan pengaruh yang sangat nyata $(\mathrm{P}<0,01)$ pada produksi gas kumulatif dan pengaruh yang tidak nyata $(\mathrm{P}>0,05)$ pada nilai $\mathrm{b}$ dan nilai $\mathrm{c}$.

Nilai b menunjukkan jumlah fraksi BO tidak larut namun dapat terdegradasi. Ramdani dkk. (2017) menjelaskan bahwa nilai $b$ memiliki hubungan yang erat dengan ketersediaan energi berupa VFA yang dihasilkan selama proses fermentasi pakan. Semakin tinggi nilai $b$, maka semakin banyak potensi BO yang mampu didegradasi oleh mikroba rumen untuk menghasilkan VFA. Nilai c merupakan laju produksi gas yang terjadi pada waktu inkubasi 0 - 96 jam dengan $\mathrm{P}_{1}$ sangat cepat difermentasi, dibuktikan dengan nilai $\mathrm{c}$ yang tinggi. Meskipun difermentasi dengan cepat, produksi gas kumulatifnya tidak tinggi. Hal ini disebabkan karena kandungan PK relatif tinggi pada perlakuan yang dimanfaatkan untuk sintesis protein mikroba sehingga menurunkan produksi gas yang dihasilkan (Firsoni dan Yunita, 2014).

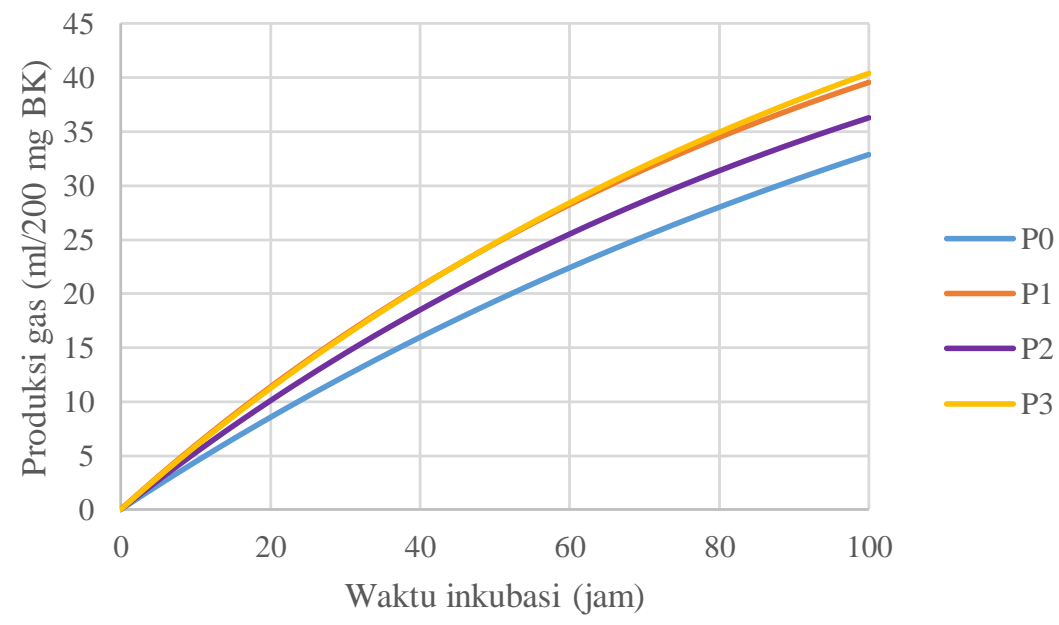

Gambar 1.Pola peningkatan produksi gas 
Gambar 1 menunjukkan semakin lama waktu inkubasi maka akan semakin meningkatkan nilai produksi gas. Hal ini disebabkan karena produksi gas memiliki keterkaitan yang erat dengan substrat dalam pakan serta aktivitas mikroba rumen. Fermentasi pakan di dalam rumen mengubah BO menjadi VFA, sel-sel mikrobial, asam lemak rantai cabang, asam amino esensial dan vitamin (terutama B kompleks) yang diserap oleh hewan inang (Pond and Bell, 2005). Fermentasi juga menghasilkan gas-gas yang terdiri dari $56 \%$ $\mathrm{CO}_{2}, 32 \% \quad \mathrm{CH}_{4}, 8,5 \% \quad \mathrm{~N}_{2}$ dan $3,5 \% \quad \mathrm{O}_{2}$ (Arora, 1989). Tingginya produksi gas yang dihasilkan menandakan tingginya aktivitas mikroba rumen dalam mendegradasi BO. Hal ini sesuai dengan Kurniawati (2007) yang menjelaskan bahwa penambahan karbohidrat mudah terdegradasi akan meningkatkan pertumbuhan mikroba rumen dan laju degradasi substrat oleh mikroba rumen. Prihartini dkk. (2007) menjelaskan bahwa semakin cepat produksi gas mencapai puncak apabila semakin banyak fraksi yang larut dan mudah terdegradasi dalam bahan pakan. Blümmel et al. (1997) menambahkan bahwa sumber energi akan meningkatkan nilai produksi gas dan sebaliknya pada sumber protein akan menurunkan nilai produksi gas setelah terjadinya proses fermentasi. Semakin tinggi populasi mikroba dalam cairan rumen, maka semakin tinggi pula BO pakan yang mampu didegradasi dan gas yang dihasilkan akan semakin meningkat (Ramdani dkk., 2017).

Degradasi residu produksi gas:

Tabel 5. Rataan nilai degradasi bahan kering (DBK) dan degradasi bahan organik (DBO) residuproduksi gas pada lama inkubasi 96 jam perlakuan setelah ensilase

\begin{tabular}{ccccc}
\hline Perlakuan & DBK $(\%)$ & DBK $(\mathrm{mg})$ & DBO $(\%)$ & DBO $(\mathrm{mg})$ \\
\hline $\mathrm{P}_{0}$ & $28,68 \pm 1,38^{\mathrm{a}}$ & 57,36 & $30,27 \pm 1,54^{\mathrm{a}}$ & 60,54 \\
$\mathrm{P}_{1}$ & $32,75 \pm 1,53^{\mathrm{b}}$ & 65,50 & $35,79 \pm 1,60^{\mathrm{b}}$ & 71,58 \\
$\mathrm{P}_{2}$ & $32,47 \pm 2,28^{\mathrm{b}}$ & 64,93 & $34,90 \pm 2,70^{\mathrm{b}}$ & 69,80 \\
$\mathrm{P}_{3}$ & $35,36 \pm 2,03^{\mathrm{c}}$ & 70,71 & $39,39 \pm 0,72^{\mathrm{c}}$ & 78,78 \\
\hline
\end{tabular}

Keterangan: ${ }^{a-c}$ Superskrip yang berbeda pada kolom yang sama menunjukkan pengaruh yang sangat nyata $(\mathrm{P}<0,01)$ pada DBK dan DBO

Hasil analisis ragam menunjukkan bahwa perlakuan silase rumput odot dengan penambahan bahan aditif berbeda memberikan pengaruh yang sangat nyata $(\mathrm{P}<0,01)$ terhadap DBK dan DBO (Tabel 5). $\mathrm{P}_{3}$ menghasilkan nilai degradasi terbaik yang disebabkan karena rendahnya kandungan SK yakni sebesar 29,74\%. Rendahnya kandungan SK menjadikan pakan lebih mudah dicerna dalam saluran pencernaan sehingga memudahkan bakteri untuk melakukan penetrasi ke dalam material pakan untuk proses pencernaan (Permana dkk., 2013). Selain itu, kandungan $\mathrm{PK}$ pada $\mathrm{P}_{3}$ dikatakan relatif tinggi yakni sebesar $12,44 \%$. Sukmawan, dkk. (2010) menyatakan tingginya kandungan protein dapat meningkatkan pertumbuhan mikroorganisme rumen yang akhirnya dapat meningkatkan laju degradasi pakan tersebut. Anwar dkk. (2017) menambahkan semakin tinggi persentase DBK dan DBO menunjukkan bahwa semakin mudah bahan pakan tersebut didegradasi oleh mikroorganisme rumen sehingga tingkat kecernaannya semakin baik.

\section{KESIMPULAN}

Penambahan bahan aditif baik pollard maupun bekatul dapat meningkatkan kualitas silase dilihat dari nilai kecernaan $\mathrm{BK}$ dan $\mathrm{BO}$, produksi gas kumulatif, nilai b dan c serta degradasi BK dan BO.Penambahan pollard $20 \%$ dalam pembuatan silase rumput odot $\left(\mathrm{P}_{1}\right)$ menghasilkan perlakuan dengan nilai 
$\mathrm{KcBK}(62,34 \%)$ dan $\mathrm{KcBO}(68,18 \%)$ tinggi, ditunjang dengan produksi gas sebesar 35,86 $\mathrm{ml} / 200 \mathrm{mg}$ BK, DBK $32,75 \%$ dan DBO 35,79\%.

\section{DAFTAR PUSTAKA}

Anwar, S., Rochana, A., \& Hernaman, I. (2017). Pengaruh tingkat penambahan complete rumen modifier (CRM) dalam ransum berbasis jerami jagung terhadap produksi gas metan \& degradasi bahan kering di rumen (in vitro). Students E-Journal, 6(1).

Arief, D., \& Arianti. (2000). Evaluasi ransum yang menggunakan kombinasi pollard \& duckweed terhadap persentase berat karkas, bulu, organ dalam, lemak abdominal, panjang usus \& sekum ayam kampung. Bogor: Institut Pertanian Bogor.

Arora, S. (1989). Pencernaan mikroba pada ruminansia. Yogyakarta: Universitas Gadjah Mada Press.

Badan Standardisasi Nasional. (2014). Hasil ikutan pengolahan biji gandum (wheat pollard \& wheat bran) - Bahan Pakan Ternak. Jakarta: Bahan Pakan Ternak.

Blümmel, M., Steingass, H., \& Becker, K. (1997). The relationship between in vitro gas production, in vitro microbial biomass yield \& $15 \mathrm{~N}$ incorporation \& its implications for the prediction of voluntary feed intake of roughages. The British Journal of Nutrition, 77(6), 911-921.
Despal, D., Permana, I. G., Safarina, S. N., \& Tatra, A. J. (2011). Penggunaan berbagai sumber karbohidrat terlarut air untuk meningkatkan kualitas silase daun rami. Media Peternakan, 34(1), 69-76. https://doi.org/10.5398/medpet.2011. 34.1.69

FAO. (2016). Feed ingredient survey. Firsoni, F., \& Yunita, R. (2014). Uji degradabilitas pakan komplit yang mengandung daun chromolaena odorata secara in-vitro. Jurnal Peternakan Indonesia, 16(2), 89-95. https://doi.org/https://doi.org/10.2507 7/jpi.16.2.89-95.2014

Hartadi, H., Lebdosoekojo, S., Prawirokusumo, S., Reksohadiprodjo, S., \& Tillman, A. (1998). Ilmu makanan ternak dasar. Yogyakarta: Gadjah Mada University Press.

Jayathilake, Y. M. H. ., Premaratne, S., Witharama, W. R. ., \& Premalal, G. G. (2012). Silage characteristics of sugarcane (sacchrum officinarum) tops in Sri Lanka. Sri Langka.

Kurniawati, A. (2013). Teknik produksi gas in-vitro untuk evaluasi pakan ternak: volume produksi gas \& kecernaan bahan pakan. Jurnal Ilmiah Aplikasi Isotop \& Radiasi, 3(1), 40-49. https://doi.org/10.17146/JAIR.2007.3 .1 .552 
Menke, K. H., Raab, L., Salewski, A., Steingass, H., Fritz, D., \& Schneider, W. (1979). The estimation of the digestibility \& metabolizable energy content of ruminant feedingstuffs from the gas production when they are incubated with rumen liquor in vitro. The Journal of Agricultural Science, 93(1), 217-222. https://doi.org/10.1017/S0021859600 086305

Musyarofah, N., Susanto, S., Aziz, S. A., \& Kartosoewarno, S. (2007). Respon tanaman pegagan (centella asiatica 1 . urban) terhadap pemberian pupuk alami di bawah naungan. Jurnal Agronomi Indonesia (Indonesian Journal of Agronomy), 35(3), 217224.

https://doi.org/10.24831/JAI.V35I3.1 335

National Research Council. (2016). Nutrient requirements of beef cattle: eighth revised edition (eighth rev). Washington, DC: National Academics Press.

Ni, K., Wang, Y., Cai, Y., \& Pang, H. (2015). Natural lactic acid bacteria population \& silage fermentation of whole-crop wheat. AsianAustralasian Journal of Animal Sciences, 28(8), 1123-1132. https://doi.org/10.5713/ajas.14.0955

Ørskov, E. R., \& McDonald, I. (1979). The estimation of protein degradability in the rumen from incubation measurements weighted according to rate of passage. The Journal of Agricultural Science, 92(2), 499-503. https://doi.org/10.1017/S0021859600 063048
Permana, H., Chuzaemi, S., \& Mariyono, M. (2015) The effect of different crude fiber on feed intake, digestibility \& vfa characteristic in the ongole crossbred cattle.

Pond, W. G., \& Bell, A. W. (2005). Encyclopedia of animal science. New York: Marcel Dekker, Inc.

Prihartini, I., Chuzaemi, S., \& Sofjan, O. (2007). Parameter fermentasi rumen $\&$ produksi gas in vitro jerami padi hasil fermentasi inokulum lignochloritik. Jurnal Protein, 15(1), 24-32.

Putra, D. A. (2017). Pengaruh penambahan pollard \& bekatul dalam pembuatan silase rumput odot (Pennisetum purpureum, cv. Mott) terhadap $\mathrm{pH} \&$ kandungan nutrient. Universitas Brawijaya. Malang.

Ramdani, D., Marjuki, M., \& Chuzaemi, S. (2017). Pengaruh perbedaan jenis pelarut dalam proses ekstraksi buah mengkudu (Morinda citrifolia L.) pada pakan terhadap viabilitas protozoa \& produksi gas in-vitro. Jurnal Ilmu-Ilmu Peternakan, 27(2), 54-62.

https://doi.org/http://dx.doi.org/10.21 776/ub.jiip.2017.027.02.07

Santos, R. J. C. dos, Lira, M. de A., Guim, A., Santos, M. V. F. dos, Junior, J. C. B. D., \& Mello, A. C. de L. de. (2013). Elephant grass clones for silage production. Scientia Agricola, 70(1), 6-11. https://doi.org/10.1590/S010390162013000100002 
Sukawan, A., Liman, L., \& Erwanto, E. (2014). Pengaruh penambahan konsentrat dengan kadar protein kasar yang berbeda pada ransum basal terhadap kecernaan protein \& kecernaan serat kasar kambing Boerawa pasca sapih. Jurnal Ilmiah Peternakan Terpadu, 2(2), 1-6. https://doi.org/http://dx.doi.org/10.23 960/jipt.v2i2.p\%25p

Tilley, J. M. A., \& Terry, R. A. (1963). A two-stage technique for the in vitro digestion of forage crops. Grass \& Forage Science, 18(2), 104-111. https://doi.org/10.1111/j.13652494.1963.tb00335.x
Wirawati, C. U., \& Nirmagustina, D. E. (2009). Studi in vivo produk sereal dari tepung bekatul \& tepung ubi jalar sebagai pangan fungsional. Jurnal Teknologi Industri \& Hasil Pertanian, 12(2), 142-147. https://doi.org/http://dx.doi.org/10.239 60/jtihp.v14i2.\%25p

Yasin, M., Malik, M. ., \& Nazir, M. . (2003). Effect of different spatial arrangements on forage yield, yield components \& quality of mott elephantgrass. Journal of Agronomy, 2(1), $52-58$. https://doi.org/10.3923/ja.2003.52.58 